\title{
ArtiFacts: Jean Louis Petit's Screw Tourniquet
}

\author{
Alan J. Hawk BA
}

$\mathrm{P}$ eople bleed when they are cut. Although physicians have been aware of this finding since time immemorial, the true cause of the phenomenon has not always been apparent. Medieval doctors believed that blood, one of the four humors (along with yellow bile, black bile, and phlegm), was synthesized in the small intestine and circulated to the liver through veins, where it diffused

A Note from the Editor-in-Chief:

We are pleased to present the latest installment of ArtiFacts. In each installment, the Collections Manager of the Historical Collections Division of the National Museum of Health and Medicine (NMHM) will present a photograph of a visually or historically interesting artifact from the museum's collection, and provide the story behind the picture. Now a National Historic Landmark, NMHM was founded as the Army Medical Museum, which was established during the Civil War to collect "specimens of morbid anatomy together with projectiles and foreign bodies removed." Its mission today is to inspire interest in and promote the understanding of military medicine - past, present, and future - to the public.

The author certifies that he, or any member of his immediate family, has no funding or commercial associations (e.g., consultancies, stock ownership, equity interest, patent/ licensing arrangements, etc.) that might pose a conflict of interest in connection with the submitted article. centrifugally into the periphery through arteries. The pulsation of the arteries expelled vaporous residue while drawing air into the body. The first surgeons performed bloodletting to reduce inflammation caused by an accumulation of blood. Their practice expanded to include the amputation of limbs due to gunshot fractures resulting from the introduction of firearms in warfare in the 13th century. Surgeons cauterized the stump with boiling oil to counteract poisoning from the gunpowder [1].

Ambroise Paré (1510-1590) noted a surgeon "... must well observe whether there be any great flux [copious

All ICMJE Conflict of Interest Forms for authors and Clinical Orthopaedics and Related Research ${ }^{\circledR}$ editors and board members are on file with the publication and can be viewed on request.

The opinions expressed are those of the writers, and do not reflect the opinion or policy of $C O R R^{\circledR}$ or The Association of Bone and Joint Surgeons ${ }^{\circledR}$.

The opinions or assertions herein are those of the author and do not represent the views of the Department of the Army, Navy or Air Force or of the Department of Defense.

\section{A. J. Hawk BA ( $\square)$}

National Museum of Health and

Medicine, Defense Health Agency, 2460

Linden Lane, Silver Spring, MD 20910 ,

USA

e-mail: alan.j.hawk.civ@mail.mil flowing] of blood present, for he shall stop it if it be too violent; but provoke it if too slow" [8]. Paré would tie a narrow cloth band around the limb just above the amputation site to retract muscles and expose the section of bone to be cut, leaving enough soft tissue to create a stump. The band compressed nerves to dull pain and, lastly, prohibit "the flux of blood by pressing and shutting up the veins and arteries" [8].

He neither specified tightness of the band nor described a mechanism to tighten it. Some surgeons of the period placed bands above and below where the surgeon would make his incision [5]. After removing the limb, Paré advocated: "Let it bleed a little according to the strength of the patient, that so the rest of the part may afterwards be less obnoxious to inflammation and other symptoms" [7]. Individual blood vessels were crimped with forceps and tied off with a suture. The band around the limb was then removed. Blood loss was something to manage and was then considered less of a health risk compared to inflammation.

However, after the English physician William Harvey (1578-1657) transformed conventional wisdom regarding blood loss when he observed 


\section{ArtiFacts}

that blood ran through a closed circulatory system. By the early $18^{\text {th }}$ century, surgeons applied Harvey's insights on blood loss prevention during amputation. One such surgeon was Jean Louis Petit (1674-1750) of France.

Petit, who had received his Master's certificate in surgery in 1700 , described the placement of a compress over major blood vessels with a cloth strip wrapped twice around the limb, which was then tied off with a stick inserted into the knot. Petit wrote: "Once this stick is placed, it is turned as one would a garrote, which is twisted to clamp the member in a circular way, and suspends circulation" [9]. Unlike Paré's band, the sole purpose of a tourniquet was to end the flow of blood into the limb about to be amputated.

Petit also invented a tourniquet with a screw tightening mechanism to suspend circulation of blood quickly and easily while minimizing pain (Fig. 1). "The operator can control it itself without another person is obliged to keep it clamped and relax as we need it as quickly as desired; Finally he just compresses the vessels we want to compress, and gently compresses the other parties; which is a perfection that some ignorant regarded as a defect" [9]. Petit was admitted to the French Royal Academy of Sciences in 1715 and appointed, due to his surgical skill and invention, as the first director of



Fig. 1 Petit's screw tourniquet, dating from the mid-19th century, is shown. (Disclosure: This image has been manipulated using dodging and burning techniques. It has been cropped to emphasize the subject.) (National Museum of Health and Medicine photo illustration by Matthew Breitbart).

the Royal Academy of Surgery by Louis XV in 1731.

The tourniquet marked a transition in surgery from managing blood loss to preventing blood loss. This concept had so quickly become common sense that Scottish surgeon Benjamin Bell (1749-1806) observed in 1801: "As the invention of the tourniquet is claimed by different persons, and even by different nations, I shall not here pretend to say from whence it originally came, but whoever was the inventor, the first with which the world was made acquainted, was exceedingly simple; insomuch, that we are now apt to be surprised at the discovery having been left to such a late date" [2]. It made the field of orthopaedic surgery possible by increasing the chances that 


\section{ArtiFacts}

a patient could survive an amputation. During the Civil War, more than 50,000 field (strap) tourniquets and 13,000 Petit screw tourniquets [10] were used in the performance of more than 29,000 amputations by surgeons of the US Army Medical Department [4].

Petit's screw tourniquet continued to be used until the late 19th century. In time, techniques for the administration of anesthesia advanced, allowing the surgeon more time to operate. Individual blood vessels were ligated or clamped using hemostats, descendants of the forceps used by Paré. By World War I, hemorrhage became a first-aid problem, usually controlled by bandaging, and "very rarely by the use of a tourniquet" [11] for fear that the limb would die if left on for more than 6 hours [6]. Rather than issue tourniquets, combat medics were trained to improvise by using a cloth strip tightened by a stick inserted in the knot, as had been described by Petit. Recognizing that the main cause of death on the battlefield was hemorrhage, US Special Forces Command mandated the issuance of tourniquets at the turn of the 21 st century, distributed to soldiers deployed to Iraq and Afghanistan. Today, every solider is issued an individual first-aid kit, which includes a tourniquet [3].

\section{References}

1. Aird W. Discovery of the cardiovascular system: From Galen to William Harvey. J Thromb Haemost., 9(Suppl. 1):118-129.

2. Bell B. A System of Surgery. Edinburgh, Ireland: Bell \& Bradsuite; 1801:41.

3. Blackbourne LH, Baer DG, Eastridge $\mathrm{BJ}$, Kheirabadi $\mathrm{B}$, Bagley $\mathrm{S}$, Kragh JF Jr, Cap AP, Dubick MA, Morrison JJ, Midwinter MJ, Butler FK, Kotwal RS, Holcomb JB. Military medical revolution: Prehospital combat casualty care. J Trauma Acute Care Surg. 2012;73:372377.

4. Bollet AJ. Civil War Medicine, Challenges and Triumphs. Tucson, AZ: Galen Press; 2002:144.

5. Kirkup J. A History of Amputation. London, UK: Springer Verlag Ltd; 2007:99.
6. Military Medical Manual. Washington, DC: National Service Publishing Co; 1931:276.

7. Pare A. Of amputations. In: Keynes $\mathrm{G}$, ed. The Apologie and Trestise of Ambroise Pare: Containing the Voyages Made Into Divers Places, With Many of His Writings Upon Surgery. New York, NY: Dover Publications; 1968:146-160.

8. Pare A. Of wounds in general. In: Keynes G, ed. The Apologie and Treatise of Ambroise Paré: Containing the Voyages Made Into Divers Places, With Many of His Writings Upon Surgery. New York, NY: Dover Publications; 1968:117129.

9. Petit JL, Chapoulaud F. [Complete Works of Jean-Louis Petit] [in French]. Limoges, France: Imprimerie de F. Chapoulaud; 1837:808809.

10. Smart C. The Medical and Surgical History of the War of the Rebellion, Medical History Part III, Volume 1. Washington, DC: Government Printing Office; 1888:966.

11. Tuttle A. Handbook for the Medical Soldier. New York, NY: William Wood and Co; 1927: 322. 